\title{
The Problem of Intercultural Communication in English Teaching in University
}

\author{
Lidan $\mathrm{Yu}$ \\ The school of foreign languages \\ Huanghe Science and Technology College \\ Zhenghzou, China
}

\begin{abstract}
To learn a foreign language, you have to master the knowledge, skills and also have to understand the language which reflected the foreign culture, so as to overcome cultural barriers, communicate with foreigners decently and effectively and have emotional communication and cross-cultural communication. This requires us to do a good job in the language teaching in university English teaching stage, we must have the language and cultural teaching communication. Therefore, how to use language correctly and appropriately is an important part of the intercultural communicative competence. Intercultural communicative competence plays a vital role for the cultivation of language and communication ability, intercultural communication is a new "edge" subject, which has a close relationship with English teaching. As the university English teachers in the new era, we should undertake the new mission, combine the language teaching with culture teaching, and develop students' intercultural communicative competence.
\end{abstract}

Keywords—intercultural Communication; English Teaching

\section{INTRODUCTION}

With today's increasing globalization of social and economic activities, people's understanding of English learning has been further enhanced. Today, people's understanding of the language is no longer limited to the narrow concept "communication tool". Language is an inseparable part of culture; it is the carrier of culture. Language reflects the characteristics of a nation; it contains not only the nation's historical and cultural background, but also the nation's views on life, life style and mode of thinking. To learn a foreign language, you have to master the knowledge, skills and also have to understand the language which reflected the foreign culture, so as to overcome cultural barriers, communicate with foreigners decently and effectively and have emotional communication and cross-cultural communication

\section{THE RELATIONSHIP BETWEEN UNIVERSITY ENGLISH TEACHING AND INTERCULTURAL COMMUNICATION.}

Culture is a very broad concept, since the beginning of twentieth Century, many philosophers, sociologists, anthropologists, historians and linguists have tried to define or classify culture from the perspective of their own respective disciplines. According to the characteristics of cultural background and language function of foreign language teaching, culture can be divided into knowledge culture and communication culture. Communication culture refers to two people from different cultural backgrounds when they communicate directly impact on the information transfer, factors that may cause the deviation or error language and non language culture, including greetings, thanks, addressing, idioms, euphemism and taboo. Foreign language teaching should turn to language education and cultural education, to cultivate students' cross-cultural communicative competence.

Contemporary USA linguist Klumsky "language teaching is culture teaching". "Culture teaching" refers to the students intercultural (national culture, foreign culture) teaching activities, guiding students to obtain rich cross-cultural knowledge, develop respect, tolerance, equality, open cross cultural attitude and objective, unbiased cross cultural ideas and world consciousness, form effective intercultural communication ability which are understanding, comparison, reference, uptake, abandon,, cooperation and communication. Culture teaching in English teaching objective is the accumulation of English culture knowledge, cultivating intercultural communicative awareness and competence. From the early 1990s, "culture teaching" concept gradually infiltrated into the university English teaching, more and more teachers and textbook writers recognized the close relationship between language and culture. While the "university English teaching requirements" (2000, hereinafter referred to as the "requirements") is defined by the English education should include "culture knowledge, culture understanding, intercultural awareness and intercultural communicative competence", "cultural awareness is also reflected in the social development and economic construction, the requirements of contemporary Chinese language talents are gradually raised ".

With the deepening of reform and opening-up, China comprehensive national strength, international exchanges become more frequent, what the country needs is for the world, have a profound understanding of foreign culture. This requires us in university English teaching stage to do a good job in the language teaching at the same time, we must have the language and cultural teaching communication. Foreign language education in the university stage is an important process to foster language quality, we must cultivate the talents who are world oriented, have a profound understanding of foreign culture. This requires us to pay attention to intercultural education in university English teaching, improve the students' English ability of intercultural communication. 


\section{THE NECESSITY OF INTERCULTURAL COMMUNICATIVE AWARENESS AND ABILITY CULTIVATION}

Cultural awareness refers to the sensitivity to the similarities and differences between the foreign culture and the native culture, as well as in the use of language in the target language (such as English) cultural awareness to adjust their language comprehension and language production. The sensitivity and awareness can be cultivated, English teaching is not only to impart knowledge, more important is the cultivation of students' communicative competence, and develop their applications in English intercultural communicative competence. People just learn a foreign language pronunciation, grammar rules and vocabulary does not mean learning the language well and communicate effectively.

In intercultural communication, if the communication between the parties can not enter the same cultural background, it is easy to produce misunderstanding, so that the communication failed. As Thomas pointed out: "syntax error can be seen from the surface, it is easy to find this error. Once this kind of mistake was found, the listener will think that the speaker lacks sufficient knowledge of the language, so it can be forgive. Pragmatic mistakes will not be treated like the grammatical mistakes, If one can speak the foreign language fluently appears pragmatic failure, he is likely to be considered impolite or unfriendly, his mistakes in communication can not be attributed to the language ability, but will be attributed to his rudeness or hostility."

The English name of "Intercultural Communication" is "inter-cultural communication"

"cross-cultural communication", It refers to native speakers and non-native speakers communication, also refers to any people have differences in language and culture background of communication. Because of the different national ecological, material, social and religious environment, resulting in a different language habits, social culture, local customs and practices and other contextual factors in their own language environment. In different cultures people have different ways of speaking or habits. Therefore, people always like to use their own words to explain the words of each other in communication, which may make inaccurate inference on the other side of the discourse conflict and disorder. Thus, important link which requires teachers take the cross-cultural education as an important link in English teaching.

\section{Cultural mistakes APPEARED IN INTER-CULTURAL COMMUNICATION}

At present, the economic development needs more and more university graduates who have a solid professional knowledge and can directly speak English with foreign experts' investors and managers to communicate. Even some students can speak some English; they often use English inappropriately in the foreign communication and make the "cultural mistakes".

Professor $\mathrm{Hu}$ Wenzhong pointed out that in the survey what he is doing, Chinese students often made four kinds mistakes related to culture and language: (1) From the perspective of sociolinguistics is not appropriate.
"Where are you from?"; If they meet foreigners on the road, they will ask "where do you come from?" ; They refused foreign friends' proposal with "I will think it over." (2) Not acceptable in the culture and customs. If they invite foreign friends to participate in social activities but do not invite their spouses, use silence to answer foreign teacher's question, expressing gratitude to say many many thanks. (3) The conflict of different value systems. If they meet the foreign friends after being apart a long time, they said "You have got no change at all." And ask foreigners' income etc. (4) Too simple or too general. Such as they think all Americans like to eat McDonald's, all British people are quiet. Through this survey, Professor $\mathrm{Hu}$ Wenzhong thinks that the cultural mistakes is more serious than the language errors, because it is easy to cause emotional unpleasant between foreigners and Chinese. Therefore, how should we use language correctly and appropriately is an important part of the intercultural communicative competence.

\section{How to CUltivate THE CONSCIOUSNESS AND ABILITY OF INTERCULTURAL COMMUNICATION}

In foreign language teaching, the necessity of language and culture teaching has become the consensus of the people, because the cultivation of communicative competence includes two aspects: Mastering the language rules and the rules of language use, namely, linguistic competence and pragmatic competence. Here language ability refers to the pronunciation, vocabulary and grammar part, namely English in listening, speaking, reading, writing and translating, the five basic skills of language use, here refers to the language used is appropriate cultural factors and rules. Language and culture are closely linked, some background knowledge of language and culture is helpful to promote the language application ability, three elements of language syllabus (pronunciation, grammar and vocabulary) teaching already had the quite perfect system, but for the intercultural teaching it should include what elements are not clear. Following from teaching and learning perspective and cognitive perspective, we talk about how to cultivate the consciousness and ability of intercultural communication.

\section{A. From the angle of values to cognize two kinds of Chinese and English culture.}

Since ancient times, Chinese people are advocating the concept which is harmony between man and nature, that is the whole concept is relatively strong, collective is more important than individual. While the West pay more attention to the individual, pay attention to personality, they are fastidious about the independence struggle.

\section{$B$. In the classroom teaching, from multiple aspects teachers and school construct a kind of rational intercultural teaching system.}

For example, the classroom teaching is the important position of cultivating students' intercultural awareness, and therefore the most important thing is to train the students' intercultural awareness and ability in the classroom; Take the culture as teaching objectives and content, set phases goals, this goal is clear and it is convenient for teacher to operate; strengthen the cultural background information introduction, 
let the students learn language and understand the culture from different angles; By using a visual media experience foreign culture in different ways, teachers may find information and use multimedia, let the students not only understand western culture but also through actual context to learn how to use the language by social application; Pay attention to cultural differences, strengthen cultural comparison, raise cultural awareness, make good culture knowledge introduction, enhance students' sensitivity to cultural differences. It is also a higher demand for teachers to cultivate intercultural communicative awareness and competence, teachers must spend a lot of time to find the corresponding teaching materials and teaching methods.

\section{CONCLUSION}

We study intercultural communication not only focus on the definition of culture and characteristics, the definition of communication as well as the relationship between culture and communication, we should focused on the cultural factors which interfere communication. Through the above analysis and research, we can clearly recognize, intercultural communicative competence is just like a bridge, combine the language ability with communicative ability. Intercultural communicative competence plays a vital role for the cultivation of language and communication ability, intercultural communication is a new "edge" subject, which has a close relationship with English teaching. As the university English teachers in the new era, we should undertake the new mission, combine the language teaching with culture teaching, develop students' intercultural communicative competence, enable students to become all-round developed students and make students become the Chinese nation great rejuvenation of mainstay!

\section{REFERENCES}

[1] Hu Wenzhong. Cultural and communicative. Foreign language teaching and Research Press, 1994.

[2] Pan Xiaohui. Analysis of intercultural communicative competence. Foreign language journal, 1996 (2).

[3] Wang Yong. The cultivation of intercultural communicative competence in language teaching. Foreign language teaching, 1998 (4).

[4] Liu Aizhen. The cultural understanding and propriety of language. Language, 2000 (2).

[5] Gu Yueguo. Cross cultural communication. Foreign language teaching and Research Press, 1997.

[6] Deng Yanchang, Liu Runqing. Language and culture. Foreign language teaching and Research Press, 1995. 